\title{
Tissue engineering: creation of an autogenic collagenous neoligament for cure of urinary stress incontinence. Reply to Petros
}

\author{
Søren Gräs • Gunnar Lose
}

Published online: 14 August 2013

(C) The International Urogynecological Association 2013

Dear Editor,

We thank Dr. Petros [1] for his interest in our recent review about tissue engineering as a potential alternative or adjunct to surgical reconstruction in treating POP [2]. Regenerative medicine is a new interdisciplinary biomedical field that is aimed at replacing or regenerating human cells, tissues or organs to restore or establish normal function [3]. A variety of biomedical approaches have been explored and traditionally, the term tissue engineering has been confined to strategies involving ex vivo creation of replacement tissue using cells and scaffolds with the intention of subsequent in vivo implantation [4]. For clarity, our review focused on such strategies.

Petros et al. implanted Mersilene tape in dogs and observed formation of collagenous tissue around the tape; following surgical removal of the tape, the collagenous tissue persisted for at least 6 weeks [5]. We acknowledge that the idea of attempting to create a ligament with a removable implant is innovative and that the procedure in a broader sense of the term may be called tissue engineering. It remains to be seen if the newly formed collagenous tissue is in fact a neo-ligament, as claimed by the authors, and not just transient scar tissue. The disappointing results from the subsequent clinical trial reported by Dr. Petros may point to the latter.

Dr. Petros states that the tissue fixation system (TFS) evolved from this experiment and that it has been successfully applied to the cure of POP. However, the minislings and anchors of the TFS are permanent implants, which to us make a great difference. Furthermore, we are not aware of any studies that demonstrate that TFS is better and/or safer than native repair or the use of other implants for the treatment of POP.

Two relevant questions concerning a future application of tissue engineering strategies to treat POP are raised by Dr. Petros: where and how do we place the cells? The TFS uses permanent minislings with permanent tissue anchors in an attempt to repair and reinforce pelvic floor ligaments. Perhaps a similar or better effect and fewer complications can be achieved with a TFS-like procedure using slings and anchors made of a degradable material loaded with autologous fibroblasts and trophic factors.

\section{References}

1. Petros PEP (2013) Tissue engineering: creation of an autogenic collagenous neoligament for cure of urinary stress incontinence. Int Urogynecol J. doi:10.1007/s00192-013-2192-x

2. Boennelycke M, Gras S, Lose G (2013) Tissue engineering as a potential alternative or adjunct to surgical reconstruction in treating pelvic organ prolapse. Int Urogynecol J 24:741-747

3. Mason C, Dunnil P (2008) A brief definition of regenerative medicine. Regen Med 3:1-5

4. Badylak SF, Nerem RM (2010) Progress in tissue engineering and regenerative medicine. Proc Natl Acad Sci USA 107:3285-3286

5. Petros PEP, Ulmsten UI, Papadimitriou J (1990) The autogenic ligament procedure: a technique for planned formation of an artificial neo-ligament. Acta Obstet Gynecol Scand 69 [Suppl 153]:43-51
This reply refers to the comment available at doi 10.1007/s00192-0132192-x

S. Gräs $(\bowtie) \cdot$ G. Lose

Department of Obstetrics and Gynecology,

Copenhagen University Hospital, Herlev, Denmark

e-mail: s.gras@dadlnet.dk 